\title{
An analysis of teamwork based on self and peer evaluation in higher education
}

\author{
A. PLANAS-LLADÓ ET AL.
}

Assessment \& Evaluation in Higher Education

[AQ0]

\section{Anna Planas-Lladó ${ }^{1}$ Feliu Lidia ${ }^{1}[A Q 5]$ Gerard Arbat $^{1}$ Joan Pujol $^{1}$ Joan Suñol $^{1}$ Fransesc Castro $^{1}$ Carolina $^{1}$ Martí $^{1}$}

1. Institute of Educational Research, University of Girona, Girona, Spain

CONTACT Anna Planas-Lladó anna.planas@udg.edu

\section{ABSTRACT}

Teamwork is one of the most important competences for most professionals, and it is therefore imperative that it be included in university education programmes, yet its evaluation continues to pose challenges. This paper reports on part of a study into the self and peer evaluation of teamwork, research which was carried out in order to analyse teamwork dynamics among students on degree courses in different disciplines, and how these relate to the outcome of teamwork and the grades obtained by each team member. The views of 351 students studying five subjects on five different degree courses were analysed, with participants divided into 95 groups. The results show that effective teamwork is related to higher grades and higher quality products. The weighting of the grade awarded to teamwork in the final subject grade conditions students' assessment of how well the team has functioned, as does the grade each student receives from their teammates. Those teams that view their team as functioning best distribute equal grades among their teammates. The results also show that those students who assess themselves positively do the same for their peers.

Keywords: Peer-evaluation ; self-evaluation ; teamwork ; assessment ; higher education

\section{The importance of teamwork}

Research on teamwork has gained in importance in recent decades. One of the main pieces of evidence for this trend is that many accreditation agencies now require that teamwork skills be developed in higher education. This is due to such skills being one of the attributes most valued by employers when recruiting new members in an organization (European Commission 2010; Agència per a la Qualitat del Sistema Universitari Català- AQU 2015; Fundación Everis 2017; Britton et al. 2017; Fathi, Ghobakhloo, and Syberfeldt 2019). Collaboration and team-based efforts have become ubiquitous in many workplaces. Due to this relatively recent development, group work (henceforth in this article we use the terms "team" and "group" and "teamwork" and "group work" interchangeably) now forms the basis of a great deal of student learning within post-secondary education, with a view to preparing students for their future professional careers. It has been incorporated as a cross-disciplinary competence in many university degrees, even if it is not always implemented in the way originally intended.

The results of studies on competence training at Spanish universities are, in part, contradictory. For example, teamwork is one of the competences with the greatest educational deficit according to graduates of universities in the autonomous region of Catalonia (Spain) (Agència per a la Qualitat dels Sistema Universitari de Catalunya- AQU 2017), whereas the study conducted by Michavila et al. (2016), which collected university graduates' perceptions four years after completing their studies, found that it is one of the most highly valued. The study by RodríguezGómez, Ibarra-Saiz, and Cubero-Ibáñez (2018) also revealed teamwork to be one of the competences that students believe they work most on in their studies. These authors studied the perceptions of 2,556 students attending 10 Span- 
ish public universities regarding ten basic competences (applying knowledge, reasoning, problem solving, analysing information, communicating, autonomous learning, sense of ethics, creativity, teamwork and evaluation). In reference to teamwork, the activities that students reported performing more frequently were "participating and collaborating actively in teamwork" and "integrating and agreeing on the contributions of the team, respecting all opinions". On the other hand, evaluation is among the competences students believe they implement least, probably due to the little training they receive in this area (Ibarra-Saiz and Rodríguez-Gómez 2014).

At the international level, teamwork or the ability to work in a team is one of the generic competences thought to be most important across all subject areas (Riebe, Girardi, and Whitsed 2016; Britton et al. 2017; Sridharan, Muttakin, and Mihret 2018). Recently, Wilson, Ho, and Brookes (2018) reviewed some studies that show how, despite the importance of acquiring it, students believe that little work is dedicated to the competence of teamwork on their syllabuses. With regard to this, several different factors make it difficult to introduce team activities in the university classroom, such as the lack of resources to implement them correctly or that they require time that is then not invested in providing content (Fathi, Ghobakhloo, and Syberfeldt 2019).

Despite these difficulties, there are many advantages to cultivating teamwork skills from a social, professional and educational point of view. These include, among others, students' active engagement, positive interdependence, individual accountability, equal participation, higher understanding and retention of concepts, social skills (Scott-Ladd and Chan 2008; Strom and Strom 2011; De Hei et al. 2015), improving democratic skills in citizenship education and co-constructing knowledge (King and Behnke 2005). However, teamwork also entails some limitations that can emerge from either individual team members or the group dynamic. On the one hand, it has been observed that lowachieving students benefit more from teamwork than those who usually achieve high marks, and on the other, both "free riding" and the presence of too many dominant or inactive members have been found to hinder group work (Pallisera et al. 2009, Channon et al. 2017). In addition, students may also be unrealistic or biased when assessing peers, and tension or friction can emerge among peers, including feelings of hurt (Vu and Dall'Alba 2007).

In order to enhance the advantages of teamwork and avoid the problems that arise when group activities are employed, it is important for teachers to include adequate tools in the programming of these activities that help students to work correctly in a group and value their involvement and that of their peers (Pujolàs 2008).

\section{Teamwork assessment}

One of the challenges of implementing teamwork in university education is assessing students' competence in it (King and Behnke 2005; Fellenz 2006; Carson and Glaser 2010; Gransberg 2010; Anson and Goodman 2014). Many teamwork experiences have assessed this competence based on evaluating the outcome of the activity involving teamwork. However, that a group receives a good mark for the tasks it has performed does not mean that all members have successfully acquired the skills of group work (Channon et al. 2017). Aside from the outcome of the task, it is necessary to assess how the group has worked together and the level of competence of each of its members. According to Channon et al. (2017), the task, individuals and group must all be taken into account for the definition "good group" to be applicable. Assessment of the latter two elements is hampered by the teachers not always being with the teams when they execute their tasks. It is the students themselves who can best perform these assessments, as they interact with the members of the group and are direct observers of both their teammates' behaviour and that of the group as a whole (Gransberg 2010; O'Neill et al. 2019). A methodology is therefore required that allows students to assess both the group and its members.

Different studies have shown the usefulness of self and peer assessment in relation to teamwork (Chapman and van Auken 2001; Fellenz 2006, Wen and Tsai 2006, Sergi 2007; Carson and Glaser 2010; Gransberg 2010; Neus 2011; Thomas, Martin, and Pleasants 2011; Weaver and Esposto 2012; Britton et al. 2017; O'Neill et al. 2019; Planas-Lladó et al. 2018). Some of these studies also show that students value the use of these techniques very positively when working as a team (Sergi 2007; Carson and Glaser 2010; Gransberg 2010; Neus 2011; Weaver and Esposto 2012; Planas-Lladó et al. 2018). Self and peer assessment also foster students' learning by helping them develop skills related to critical thinking, self-regulation and problem solving (Kiliç 2016).

Many methods and instruments have been devised to aid self and peer assessment (King and Behnke 2005), with researchers, educators and organizations often creating their own (Loughry, Ohland, and Moore 2007). Some of the tools that have been developed to evaluate teamwork employ rating scales. One of the most widely used is the Com- 
prehensive Assessment of Team Member Effectiveness (CATME) (Ohland et al. 2012), which is available as a webbased tool (Loughry, Ohland, and Moore 2007). CATME helps students learn how to contribute to teamwork and assess team members' contributions to it. Although the usefulness of the tool has been proven, Hastie, Fahy, and Parratt (2014) have described some limitations, such as its online application, which prevents it being adapted to specific needs. The instrument is also in English, and therefore not so easy to apply outside the English-speaking world.

Among the different methods that use peer assessment to evaluate teamwork, we find the Croft peer-evaluation method (Croft, Meyers, and Fentimen 1995), which consists in the students themselves distributing points between the different team members once the activity is completed. This allows them to reward those students who have done a better job with more points and penalize those who have not participated enough in the group with fewer points. It involves students evaluating themselves, their teammates and the group as a whole. Although some groups may tend to share out points equally to avoid confrontations or negative feelings (Fellenz 2006; Ohland et al. 2012), many groups have been found to distribute the points unevenly, giving more points to those students who have acted as leaders, for example, and fewer points to those who have not done the tasks proposed by the deadline agreed within the group (Fellenz 2006; Gransberg 2010; Planas-Lladó et al. 2018). This evaluation can be equated to holding members to account for teamwork at the end of the activity, which can motivate students to become more involved in tasks and respond positively towards their teammates' expectations (O'Neill et al. 2019). However, the design of a system to include peer evaluation in calculating individual scores for team projects should be kept as simple as possible (Gransberg 2010). It should also be taken into account that, despite students having favourable attitudes towards peer assessment, many of them: (a) do not feel comfortable evaluating one another; (b) can feel unqualified to evaluate their teammates; (c) can question the objectivity of the evaluation (both their own and their teammates'); and d) see the lack of training and prior experience in evaluation as a problem (Walker 2001).

However, as Ohland et al. $(2012,611)$ pointed out, "point distributions do not give students information about what teamwork behaviors are important, and so they do not teach team skills or provide specific feedback for improvement". For this reason, introducing tools that involve students' reflection on their teammates and their own participation can facilitate the evaluation of teamwork, leading to more accurate marks (Villardón 2006; Thomas, Martin, and Pleasants 2011; Anson and Goodman 2014; Planas-Lladó et al. 2018). As Gómez-Ruiz, Rodríguez-Gómez, and Ibarra-Saiz (2013) found in their research, such reflection helps students further enhance their basic competences. Furthermore, reflection on how the team works together as a whole provides the different team members with feedback from their teammates on their participation in obtaining the final product of teamwork and the degree to which the competence in teamwork was acquired. This feedback can help reduce free riding and improve teamwork, encouraging student engagement in teamwork issues, feedback, learning and action planning (Gabelica et al. 2012). In addition, O’Neill et al. (2019) and Brutus and Donia (2010) have observed that students and teachers support the use of reflection in teaching activities.

Although many experiences have been described in which peer assessment is used to evaluate teamwork in university subjects, more in-depth research is required into this form of evaluation. In some peer assessment and self assessment experiences aimed at evaluating teamwork, the marks awarded by the students themselves have been compared with those given by their teammates (Lejk and Wyvill 2001; O'Neill et al. 2019). When a student's self assessed marks are in line with those of their peers, this indicates that said student has a correct perception of him or herself (Paunonen and O'Neill 2010; O'Neill et al. 2019). In most cases, these types of students are the ones who perform better in teamwork and produce the expected results (Fleenor et al. 2010). On the other hand, those students who award themselves higher marks than those received from their peers tend to perform at a lower level in teamwork activities (Atwater and Yammarino 1992, 1997). In respect of this, Lejk and Wyvill (2001) found that stronger students tend to under-rate themselves while weaker students have a tendency to over-rate themselves. It has also been found that inter-rater reliability in peer ratings can be improved if students do such activities over time (Loignon et al. 2017; O’Neill et al. 2017; Nejad and Mahfoodh 2019).

In order to conduct a more in-depth analysis of teamwork evaluation via peer and self assessment, we believed it would be interesting to analyse the relationship between the mark awarded to the team's product and the assessments that students make of different aspects of how the team worked together, as well as the relationship between the latter and self and peer assessment taking into account the weight of the team mark in the final grade for the subject, field and year of study.

\section{Objectives and methodology}


In order to provide more information on the dynamics of teamwork carried out by students at the academic level, a study was undertaken by the University of Girona's Network of Educational Innovation in Evaluation, which comprises professors from different disciplines and three different faculties and centres (social sciences, science and engineering). The aim of this study was to analyse the working dynamics of student teamwork on degree courses in different disciplines, and how these relate to the result and the mark obtained by one of its members. The specific aims were to analyse: (a) the group's assessment of its own teamwork process; (b) students' self-evaluation of their teamwork process; (c) students' peer evaluation of their teammates; and (d) how students distribute the mark for the teamwork product. The results have been analysed according to the scope, academic year and weight of the teamwork mark in the final grade for the subject using SPSSX.

The study involved a group activity being undertaken by students, who then assessed the teamwork that had taken place and expressed their opinion on this assessment method. It was carried out in five subject areas - one from social sciences, one from science and three from engineering - on five different degree courses, over two consecutive academic years (Table 1). The group activity consisted in preparing and making oral presentations and producing written assignments, projects, spreadsheets or business plans. The number of students who took part in each activity ranged from 36 to 125 , divided into 17-28 groups of 2 to five members each. Aside from the content involved in each activity, these educational activities also aimed to foster students' active participation in teamwork and have them take responsibility for and involve them in assessment. To add weight to the work of student assessment, in each subject the mark awarded by peers was worth $5-55 \%$ of the final mark for the subject. None of the students had prior experience of using peer assessment to evaluate teamwork, although some of them had experience of peer assessment in other activities.

Table 1. Overview of the characteristics of subjects considered in the study.

\begin{tabular}{|c|c|c|c|c|c|}
\hline Course & Project design & $\begin{array}{c}\text { Social and legal } \\
\text { aspects of biotech- } \\
\text { nology }\end{array}$ & Physics & Structures & $\begin{array}{c}\text { Business organiza- } \\
\text { tion and manage- } \\
\text { ment }\end{array}$ \\
\hline Subject & $\begin{array}{l}\text { Social Educa- } \\
\text { tion }\end{array}$ & Biotechnology & $\begin{array}{l}\text { Agricultural } \\
\text { Engineering }\end{array}$ & $\begin{array}{l}\text { Agricultural En- } \\
\text { gineering }\end{array}$ & $\begin{array}{l}\text { Agricultural Engi- } \\
\text { neering }\end{array}$ \\
\hline Field & Social Sciences & Science & Engineering & Engineering & Engineering \\
\hline Year & Second & Third & First & Second & First \\
\hline $\begin{array}{l}\text { Number students } \\
\text { (Number groups) }\end{array}$ & 125 (28 groups) & 97 (24 groups) & 36 (18 groups) & 60 (17 groups) & 83 (25 groups) \\
\hline Activity & Project work & Oral presentation & Project work & $\begin{array}{l}\text { Spreadsheet and } \\
\text { project work }\end{array}$ & Business plan \\
\hline $\begin{array}{l}\text { \% of final course } \\
\text { mark }\end{array}$ & $50 \%$ or $55 \%$ & $5 \%$ & $20 \%$ & $15 \%$ & $20 \%$ \\
\hline $\begin{array}{l}\text { Prior experience in } \\
\text { peer assessment activ- } \\
\text { ities }\end{array}$ & Yes & Yes & No & Yes & No \\
\hline $\begin{array}{l}\text { \% of groups with un- } \\
\text { even mark distribu- } \\
\text { tion }\end{array}$ & $39.3 \%$ & $20.8 \%$ & $5.5 \%$ & $29.4 \%$ & $40 \%$ \\
\hline
\end{tabular}

The same methodology was employed in all of the subjects and comprised the following steps:

1. Prior to the activity, joint preparation of documents for students to carry out self and peer teamwork assessment by all members of the University of Girona's Network of Educational Innovation in Evaluation. These documents included an individual report, a group report and a rubric. The aim of the individual report was for students to assess themselves and their peers, while the group report was to assess teamwork as a whole. In both cases, evaluation entailed awarding 
marks on a Likert scale of 1-4 and students could provide arguments and evidence for their evaluation. The assessment indicators included in these two reports were related to the eight basic behavioural components reviewed by Baker (2008): attendance at group meetings, dependability and keeping one's word, quality of work, effort and/or extra effort, cooperation and communication with other members, management of group conflict, making cognitive contributions, and structuring group work for goal achievement. The rubric was provided to help students complete the individual report.

2. In the next step, the professors responsible for the subjects provided students with a detailed explanation of the teamwork assessment process. They also explained and provided the documents necessary for the evaluation: the two reports and the rubric.

3. Execution of the teamwork activity on the course.

4. After the activity was carried out:

5. Individual and group assessment of teamwork by students using the individual and group reports and rubric.

6. Marking of the activity by professor (taking the rubric into account). Groups were then informed of their mark so that they could distribute it among their peers.

7. Distribution of the mark between members of each group based on the reflective work done in individual and group reports. For example, if the final teamwork mark was a 7 and the team was composed of four students, the group had 28 points to distribute among the members of the team. Groups had the autonomy to decide by consensus whether the mark should be the same for all members, or whether to differentiate based on the level of involvement and work done by each member. Once decided, they had to submit a report to the professor with the mark distribution. The mark in the report was the one given to each student as a final mark for teamwork. The assessment system applied was a modified version of the method first posited by Croft, Meyers, and Fentimen (1995).

The data were processed using the SPSSv.23 program. The statistical analysis was based on the correlations and comparisons between the final mark obtained for each group, the distribution of these marks between each member of the group, and the teamwork items evaluated by the students in the individual and group reports. The work involved a total of 403 students, distributed into 112 working groups. A total of 351 individual reports and 95 group reports were analysed. The distribution of points was analysed using the total number of students and groups, while the evaluations were analysed using the assessment reports. Not all individual and group reports were available, meaning that the sample is smaller in both cases.

\section{Results}

\section{Group evaluation of teamwork}

The group reports were analysed based on the mark obtained by the team, the weight of teamwork in the final grade, the field and the academic year.

The student groups had a positive overall perception of teamwork. The results showed that groups whose teamwork process was viewed as good received more positive marks for the products of the activities they conducted and experienced greater satisfaction with regard to the teamwork process. Applying Pearson's correlation, a positive relationship was observed between the group's mark and most of the group's scores for the items in the group report (Table 2). The correlation was positive for all issues related to teamwork functioning well, such as those referring to the time and place arranged for meeting, discussion of and agreement on a joint work plan, equal distribution of work, and resolving conflicts and differing points of view. Thus, the group functioning translated into a better job being done and therefore a better mark.

Table 2. Pearson's correlation between the items related to teamwork performance in the group report and the group mark, and the same items and the percentage weighting of the teamwork mark in the final grade. 


\begin{tabular}{|c|c|c|c|c|c|c|c|c|c|c|}
\hline & \multicolumn{9}{|c|}{ Items from group report } & \multirow[t]{2}{*}{ Mean score } \\
\hline & 1 & 2 & 3 & 4 & 5 & 6 & 7 & 8 & 9 & \\
\hline GROUP MARK & $.271 * *$ & $.231 * *$ & $.251 * *$ & .062 & $.227 * *$ & .033 & $.223 * *$ & -.031 & $.248 * *$ & $.313 * *$ \\
\hline$\%$ MARK OVER FINAL & $-.262 * *$ & $-.129 *$ & $-.199 * *$ & -.071 & $-.164 * *$ & $-.175 * *$ & $-.232 * *$ & -.054 & -.007 & $-.252 * *$ \\
\hline
\end{tabular}

** The correlation is significant at level 0.01 (bilateral).

* The correlation is significant at level 0.05 (bilateral).

When correlating the percentage of the teamwork mark in the final grade with group evaluations, it was observed that the greater the weighting teamwork had in the final grade, the lower the scores awarded for teamwork. Thus, the greater the weight of the teamwork mark, the stricter the scores given for the team's performance.

When analysing the differences between the fields of the group evaluations for the items in the group report, it was observed that the groups studying degrees in a scientific field tended to award higher group marks (Figure 1). This was followed by those in the field of technology and, finally, those in the social field. Caution must be taken with these data, since the subject of science gives the least weight to the teamwork mark in the final grade and the subject social science gives the most. However, some specific items are very similar in all fields. These are: "One of the team members acted as a reference point, leading the process" (Item 4), "The team members had the freedom to express their opinions and proposals at all times" (Item 6) and "The team members respected the decisions taken in the group work spaces" (Item 8) (Figure 1).

Figure 1. Comparison among the different fields for item evaluations in the group report (scores between 1 and 4).

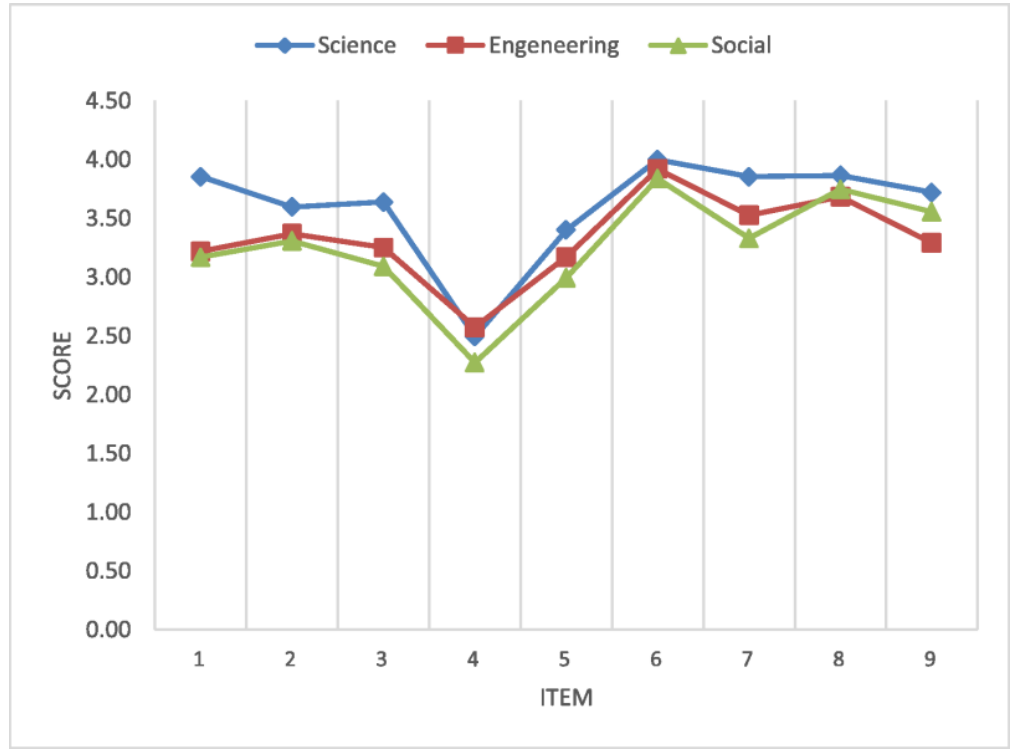

When comparing group scores for items related to the team's performance by academic year, few differences were observed. The third-year groups generally valued the items more positively, while the first years valued all items more evenly (Figure 2). One finding that also stood out was the difference in the score awarded to Item 4 (One of the team members acted as a reference point, leading the process) by the first-year groups compared to the groups in other years. The former tended to have a clear group leader who led the teamwork process, while the second and third-year groups divided up responsibility for the tasks more.

Figure 2. Comparison of scores for the items in the group report by academic year (scores of between 1 and 4). 


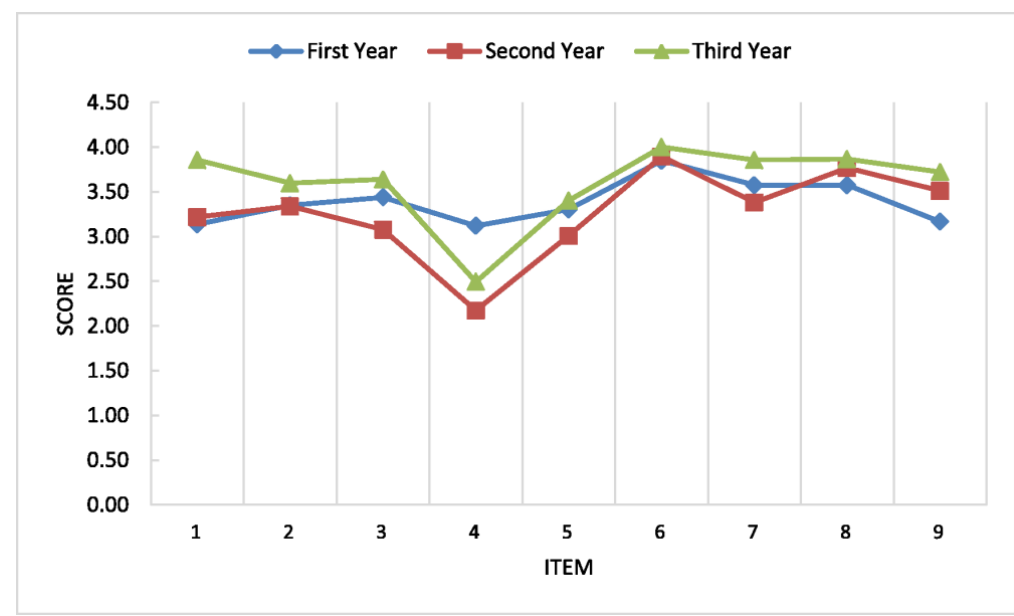

\section{Group evaluation of teamwork and its relationship with mark distribution}

The evaluation of teamwork performance is also related to how marks are distributed by team members. Students tended to distribute the mark equally in our study, with $71.4 \%$ of the groups doing so and $28.6 \%$ not.

The type of mark distribution (equal or unequal) was analysed by academic field, year and weight of teamwork mark in the final grade for the subject (Table 3). The number of groups distributed unevenly was greater in the social field. The greater the weight of the teamwork mark, the more uneven the distribution of points was found to be. As for type of mark distribution by academic year, the data obtained did not allow us to draw any conclusions.

Table 3. Type of mark distribution by academic field, year of study and weighting of teamwork mark in final grade for subject.

\begin{tabular}{|c|c|c|c|c|c|c|}
\hline & & \multicolumn{4}{|c|}{ TYPE OF DISTRIBUTION } & \multirow[t]{3}{*}{ TOTAL GROUPS } \\
\hline & & \multicolumn{2}{|c|}{ EQUAL } & \multicolumn{2}{|c|}{ UNEQUAL } & \\
\hline & & No. & $\%$ & & $\%$ & \\
\hline \multirow[t]{3}{*}{ FIELD } & Scientific & 19 & 79.1 & 5 & 20.9 & 24 \\
\hline & Technological & 44 & 73.3 & 16 & 26.7 & 60 \\
\hline & Social & 17 & 60.7 & 11 & 39.3 & 28 \\
\hline \multirow[t]{3}{*}{ YEAR } & First & 32 & 74.4 & 11 & 25.6 & 43 \\
\hline & Second & 29 & 64.4 & 16 & 35.6 & 45 \\
\hline & Third & 19 & 79.1 & 5 & 20.9 & 24 \\
\hline \multirow[t]{5}{*}{$\%$ FINAL GRADE } & $5 \%$ & 19 & 79.1 & 5 & 20.1 & 24 \\
\hline & $15 \%$ & 12 & 70.6 & 5 & 29.4 & 17 \\
\hline & $20 \%$ & 32 & 74.4 & 11 & 25.6 & 43 \\
\hline & $50 \%$ & 8 & 57.1 & 6 & 42.9 & 14 \\
\hline & $55 \%$ & 9 & 64.3 & 5 & 35.7 & 14 \\
\hline \multicolumn{2}{|l|}{ TOTAL } & 80 & $71.4^{\circ}$ & 32 & $28.6 \%$ & 112 \\
\hline
\end{tabular}

We also analysed the relationship between type of mark distribution and the mean scores for all of the items in the group report and the mean for each item. Groups with an equal mark distribution tended to evaluate teamwork per- 
formance more positively (mean: 3.42 and standard deviation: .39) than those with an unequal distribution (mean: 3.29 and standard deviation: .52).

As for the mean scores that groups gave to each item in the report, some differences were found between the two types of mark distribution (equal-unequal) (Figure 3). The first factor to emphasize is the difference in score for the item "One of the team members acted as a reference point, leading the process" (Item 4), more agreement being found among those groups with an uneven mark distribution. We can therefore assume that if distribution is unequal, someone takes control. Two further items that stood out were "All team members worked with the same intensity in group tasks" (Item 5) and "The distribution of work that could not be finished in the joint sessions was equal and by consensus" (Item 3), which were valued more positively by groups with an equal mark distribution. Thus, when mark distribution is equal, it is perceived that all members work with the same intensity.

Figure 3. Item group scores by mark distribution (1-4 scale).

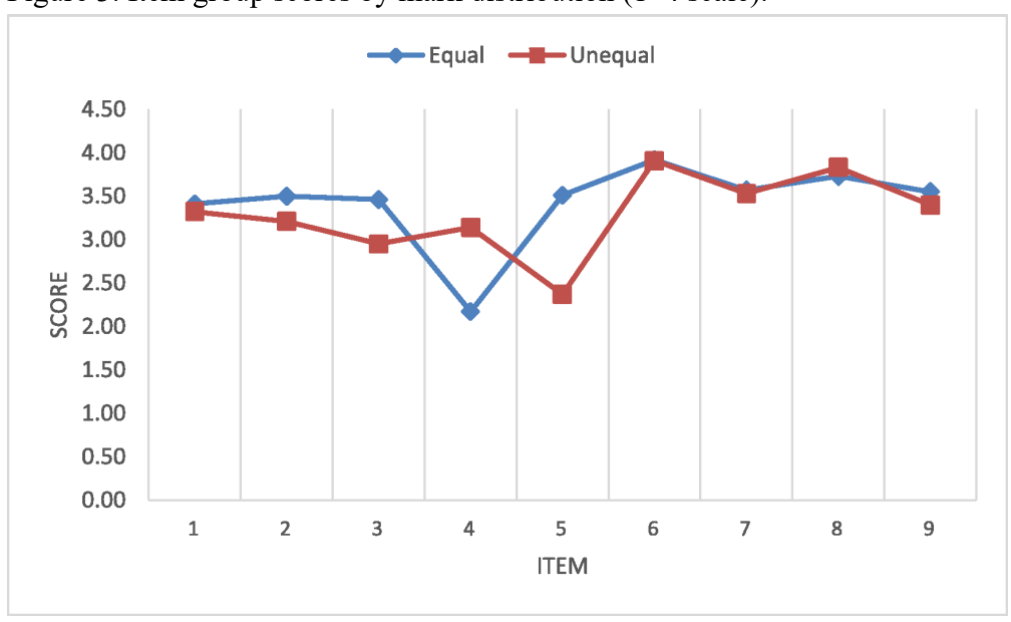

A higher dispersion (deviation) of results was also observed for the different items evaluating the team's performance when contrasted with mark distribution (Table 4). Those groups with an equal mark distribution returned similar scores, while the scores of those with an unequal distribution were slightly more dispersed. This finding reinforces the idea that groups with an unequal mark distribution have more uneven and less balanced work processes within the teams.

Table 4. Evaluation of items related to team performance by type of mark distribution.

\begin{tabular}{|c|c|c|c|c|c|c|c|c|c|c|c|}
\hline \multirow{2}{*}{\multicolumn{2}{|c|}{ DISTRIBUTION }} & \multirow{2}{*}{ Mean score } & \multicolumn{9}{|c|}{ Items in the group report } \\
\hline & & & 1 & 2 & 3 & 4 & 5 & 6 & 7 & 8 & 9 \\
\hline \multirow[t]{3}{*}{ EQUAL } & Mean & 3.4229 & 3.41 & 3.5 & 3.46 & 2.17 & 3.51 & 3.92 & 3.57 & 3.73 & 3.55 \\
\hline & Standard deviation & 0.3961 & 0.786 & 0.666 & 0.847 & 1.079 & 0.69 & 0.315 & 0.711 & 0.573 & 0.677 \\
\hline & Range & 1.78 & 3 & 3 & 3 & 3 & 3 & 2 & 3 & 3 & 3 \\
\hline \multirow[t]{3}{*}{ UNEQUAL } & Mean & 3.2946 & 3.32 & 3.21 & 2.95 & 3.14 & 2.37 & 3.91 & 3.53 & 3.83 & 3.4 \\
\hline & Standard deviation & 0.5233 & 0.91 & 0.848 & 0.93 & 0.848 & 0.874 & 0.454 & 0.907 & 0.572 & 0.832 \\
\hline & Range & 2.67 & 3 & 3 & 3 & 3 & 3 & 3 & 3 & 3 & 3 \\
\hline \multirow[t]{4}{*}{ TOTAL } & Mean & 3.3854 & 3.38 & 3.41 & 3.31 & 2.45 & 3.18 & 3.92 & 3.55 & 3.76 & 3.5 \\
\hline & $\mathrm{N}$ & 339 & 339 & 339 & 339 & 339 & 339 & 339 & 339 & 339 & 339 \\
\hline & Standard deviation & 0.4402 & 0.824 & 0.735 & 0.9 & 1.108 & 0.909 & 0.36 & 0.773 & 0.573 & 0.727 \\
\hline & Range & 2.67 & 3 & 3 & 3 & 3 & 3 & 3 & 3 & 3 & 3 \\
\hline
\end{tabular}




\section{Self and peer assessment of teamwork}

We also studied the relationship between students' self and peer assessments in relation to teamwork performance. The data were extracted from the 351 individual reports submitted by students. To this end, we calculated the mean self assessment mark students gave themselves (Mean_Self-assessment) and the mean score they gave to their peers (Mean_peer-assessment) (Figure 4). A positive correlation (.613**) was observed between the two. As can be seen in Figure 4, scores followed a positive trend and were fairly well grouped together. This means that when students assess themselves positively, they tend to do the same for their peers.

Figure 4. Pearson's correlation between students' self and peer assessment.

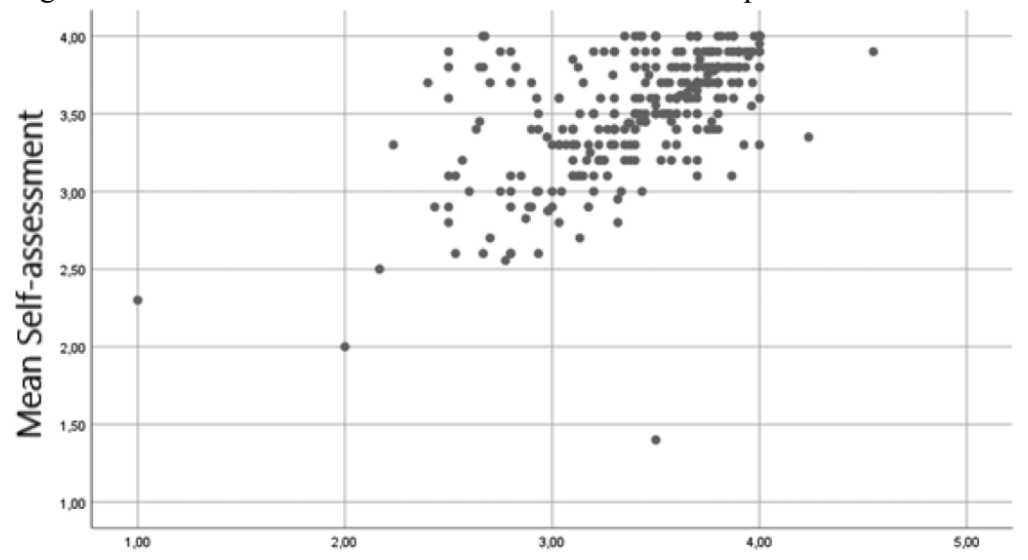

\section{Mean Peer-assessment}

The mean self assessment scores were compared to the means for peer assessment by academic field, year and weighting of the teamwork mark in the final grade. An analysis by fields shows that students in the technological and social fields tended to present similar behaviours in self and peer assessment. Thus, when students assessed themselves positively, they also often did the same for their peers. In the scientific field, this correlation was not so strong (Table 5).

Table 5. Pearson's correlation between self and peer assessments by academic field, year and weighting of mark in final grade.

\begin{tabular}{|c|c|c|c|}
\hline & & & Mean Peer assessment and Self assessment \\
\hline \multirow{6}{*}{ FIELD } & \multirow{2}{*}{ Scientific } & Mean (Pearson) & $.375^{* *}$ \\
\hline & & \begin{tabular}{|c|}
$\mathrm{N}$ \\
\end{tabular} & 95 \\
\hline & \multirow[t]{2}{*}{ Technological } & Mean (Pearson) & $.617^{* *}$ \\
\hline & & $\begin{array}{ll}\mathrm{N} \\
\end{array}$ & 159 \\
\hline & \multirow[t]{2}{*}{ Social } & Mean (Pearson) & $.625 * *$ \\
\hline & & \begin{tabular}{|l|}
$\mathrm{N}$ \\
\end{tabular} & 97 \\
\hline \multirow[t]{6}{*}{ YEAR } & \multirow[t]{2}{*}{ First } & Mean (Pearson) & $.684 * *$ \\
\hline & & \begin{tabular}{|l|}
$\mathrm{N}$ \\
\end{tabular} & 107 \\
\hline & \multirow[t]{2}{*}{ Second } & Mean (Pearson) & $.561 * *$ \\
\hline & & $\mathrm{N}$ & 149 \\
\hline & \multirow[t]{2}{*}{ Third } & Mean (Pearson) & $.375 * *$ \\
\hline & & \begin{tabular}{|l|}
$\mathrm{N}$ \\
\end{tabular} & 95 \\
\hline
\end{tabular}




\begin{tabular}{|l|c|c|c|}
\hline \multirow{2}{*}{ \% FINAL GRADE } & 5 or $15 \%$ & Mean (Pearson) & Mean Peer assessment and Self assessment \\
\cline { 2 - 4 } & $20 \%$ & $\mathrm{~N}$ & $.466^{* *}$ \\
\cline { 2 - 4 } & & Mean (Pearson) & 147 \\
\cline { 2 - 4 } & $\mathrm{N}$ & $.684^{* *}$ \\
\cline { 2 - 4 } & 50 or $55 \%$ & Mean (Pearson) & 107 \\
\cline { 2 - 4 } & $\mathrm{N}$ & $.625^{* *}$ \\
\hline
\end{tabular}

** The correlation is significant at level 0.01 (bilateral); N. Number of students; Sig (bilateral) is 0.000 in all cases.

The analysis by academic year indicates a positive correlation between self and peer assessments among first and second-year students. This finding shows that these students tended to give their peers better marks when they also gave themselves a high mark. In contrast, the scores awarded by third-year students showed a higher dispersion and a lower correlation (Table 5).

Furthermore, it was also observed that students' assessments were not related to the weighting of the teamwork mark in the final grade for the subject, although there was slightly less correlation between these assessments and the weighting of the mark when the weighting was lower. That tasks with little weighting in the final grade require less involvement on the part of team members could explain this finding (Table 5).

An analysis of the individual reports revealed that when teamwork had a higher weighting in the final grade of the subject, individual self assessments were lower. This was observed when correlating the mean self assessment for each item in the individual report with the percentage weighting of the teamwork mark in the final grade (Table 6). The same trend was observed for peer assessment means $(-192 * *)$.

Table 6. Pearson's correlation between students' mean self assessments for each item related to teamwork performance (individual report) and the percentage weighting of the teamwork mark in the final grade of the subject.

\begin{tabular}{|l|r|}
\hline & $\%$ FINAL MARK Pearson's correlation \\
\hline Attendance & $-.259^{* *}$ \\
\hline Participation and collaboration & $-.153^{*}$ \\
\hline Time and task management & $-.261^{* *}$ \\
\hline Distribution of tasks and responsibilities & $-.136^{*}$ \\
\hline Working to objectives & -.068 \\
\hline Positive attitude and cohesion & -.113 \\
\hline Assertive communication & $-.128^{*}$ \\
\hline Leadership & $-.230^{* *}$ \\
\hline Self - analysis & $-.175^{* *}$ \\
\hline
\end{tabular}

**The correlation is significant at level 0.01 (bilateral).

*The correlation is significant at level 0.05 (bilateral).

The mean evaluation for items in the individual report on the teamwork process was similar for each academic field. However, the mean evaluations by students in the scientific field were slightly higher than those in the technological and social fields, a behaviour that was also observed in the case of the group report evaluations.

In the same analysis by academic year, virtually no differences were found between the different years with regard to individual evaluations of teamwork performance.

Finally, correlating students' self and peer assessments with the final teamwork mark showed that when the group mark was higher, the item scores increased. As can be seen in Table 7, the item that correlated least in this respect 
was that of leadership ("One of the members of the team acted as a reference point, leading the process"). When the group mark was higher, leadership was more divided among the team members, and therefore received lower scores; this was also observed in the analysis of team marks. When groups received higher marks for the assessed activity, students gave a higher mark to teamwork performance items related to overall assessment, time and task management, participation and collaboration, self-analysis and working to objectives. A similar behaviour was observed in the case of peer evaluations (Pearson's correlation mean group mark other peers .297**).

Table 7. Pearson's correlation between the group's final mark and self assessment for each item.

\begin{tabular}{|l|r|}
\hline & GROUP MARK Pearson's correlation \\
\hline Attendance & $.123^{*}$ \\
\hline Participation and collaboration & $.223^{* *}$ \\
\hline Time and task management & $.243^{* *}$ \\
\hline Distribution of tasks and responsibilities & $.173^{* *}$ \\
\hline Working to objectives & $.222^{* *}$ \\
\hline Positive attitude and cohesion & $.200^{* *}$ \\
\hline Assertive communication & $.126^{*}$ \\
\hline Leadership & .035 \\
\hline Self-analysis & $.216^{* *}$ \\
\hline Overall evaluation & $.297^{* *}$ \\
\hline
\end{tabular}

**The correlation is significant at level 0.01 (bilateral).

*The correlation is significant at level 0.05 (bilateral).

\section{Discussion and conclusions}

Teamwork is one of the competences that employers identify as being most important in the human resources selection process (European Commission, 2010; Agència per a la Qualitat del Sistema Universitari Català- AQU2015; Fundación Everis 2017), which is why both students and professors agree on the need to develop it in the university domain (Brutus and Donia 2010; O’Neill et al. 2019). Although university students engage in team activities, they are not generally aware of how team dynamics work, what roles members take, the barriers to progress and which aspects the team masters and help it obtain the expected results. In addition, university students have little experience in evaluating this competence. Consequently, the implementation of practical team activities is fundamental, especially if it is accompanied by evaluation and reflection on the process. Knowing the parameters that can influence teamwork and its evaluation is also of great relevance. In order to expand scientific knowledge in this area, the present research studied team activities carried out within subjects in different fields of university study, including self and peer assessment by students to assess teamwork (individual reports) and student reflection on the teamwork process (group reports). It provides evidence of group behaviours in relation to different variables, in particular the quality of products resulting from teamwork, the weight of the teamwork mark in the final subject grade, the mark distribution among team members and training students in teamwork.

The results of the study show that team performance is closely related to the quality of work produced, and consequently the mark obtained for the products of activities. Thus, those groups that rate their performance positively usually receive higher marks for the outcome of their teamwork, demonstrating the importance of carrying out an efficient teamwork process to obtain good results.

In addition, the results also reveal that the percentage of the teamwork mark in the final subject grade conditions students' assessment of teamwork performance, in relation to both the individual and group reports, and also how students distribute marks when assessing teamwork. Thus, the more weight teamwork has in the final grade, the stricter students are when assessing the process and the greater balance there is between groups that distribute the mark equally and those that do not. This indicates that students feel more involved in teamwork when its impact on the final grade is higher, and as a result are also more demanding of their peers. Contrarily, those activities with little 
weight in the final grade are usually perceived as being easier and less relevant, and require little involvement on the part of team members. Therefore, they award their peers higher marks and, moreover, groups are more likely to distribute the mark equally. These results coincide with those of Sridharan, Muttakin, and Mihret (2018), who stated that the percentage weighting given to peer assessment should be sufficiently high to avoid parasitism, improve communication within the team and increase the contribution of team members.

This study also reveals a relationship between teams' group evaluation and the mark distribution when evaluating teamwork. Specifically, the team's performance is assessed more positively among those groups that distribute the mark equally and receive similar marks from each other. In these groups, items that are highly valued refer to equal task distribution, working by consensus, and similar intensity of work among all team members. Contrarily, they do not attach a high value to clear leadership, something that is observed among those groups with an uneven mark distribution.

The results also show that as students acquire the competence of teamwork, their behaviour as a group changes over time. On the one hand, whether they have a leader changes. Teams of first-year students tend to have a clear leader to lead the process, while those in the second and third years divide the tasks up more. On the other hand, a positive correlation is also observed between self and peer assessment, and this correlation is higher among first and second-year students than among third-years. Thus, the more positive the self assessment, the more favourable the peer assessment. According to O'Neill et al. (2019) and Paunonen and O'Neill (2010), this means that students have a correct perception of themselves. Moreover, several authors have shown that teamwork competence improves when it is put into practice continuously over time (Brutus and Donia 2010; Biggs and Tang 2011; Britton et al. 2017). This could be because third-year students have more experience in group activities than those in earlier years and are therefore more capable of distinguishing between good and bad practices in this competence. Also, as Nejad and Mahfoodh $(2019,626)$ point out, "assessment practices would help students sharpen their assessment abilities, which in turn can give rise to more reliable scores".

In line with that observed in previous research (Anson and Goodman 2014), this study shows that groups' reflection on their team performance, as well as individuals' reflection on their own work and that of their peers, constitutes a very effective tool for fostering student involvement in teamwork. Reflection also helps to create an interdependence between the different team members, providing a sense of group cohesion, team awareness, and individual and inter-individual responsibility ( $\mathrm{O}^{\prime} \mathrm{Neill}$ et al. 2019). We are convinced that the feedback and reflection process through self and peer assessment constitute very important training exercises for students that help them develop the competence of teamwork, as pointed out by Ohland et al. (2012). In order for it to work as a training exercise, it is important to bear in mind that the evaluation procedure must be clearly explained to students prior to peer evaluation so that they understand the aims of the process and the tools to be used (Falchikov and Goldfinch 2000; Fellenz 2006; Cestone, Levine, and Lane 2008; Vu and Dall'Alba 2007; Planas-Lladó et al. 2018); practical examples must also be provided (Kiliç 2016). These measures give students confidence and make the evaluations fairer. It is also important to provide them with tools to make the process a reflective one. Among these, we would highlight the use of rubrics.

One strength of the study presented here is that it involves subjects from very different fields (social, technological and scientific), and the results therefore have a high degree of transferability. Most teamwork evaluation methodologies described in the scientific literature apply to a very specific field and are therefore only useful for the subject for which they have been designed (Britton et al. 2017). It is worth noting that our work as a whole shows how a common self and peer assessment method for evaluating teamwork can be applied across a range of very different disciplines in higher education.

Among the limitations of this study, we would highlight its focus on specific subjects from various degree courses in which students display different levels of teamwork competence and professors are committed to using a pedagogical and reflective approach to teamwork in the classroom. In most cases, these are isolated subjects within a degree subject. A regular and gradual use of this methodology for evaluating teamwork at the bachelor or faculty level would help to show the progress students make in this competence (O'Neill et al. 2019) and improve its acquisition. Another limitation of the study is that student feedback is given through reflection reports and teacher feedback. In subsequent experiences, the incorporation of more structured and recurrent feedback processes where students see their peers' evaluation is recommended. We also believe that no relevant conclusions can be drawn from the analysis by academic field. In all cases, behaviour in the scientific field differed from that of the other fields. One possible 
explanation for this may be that the scientific field is the only one to include this subject matter in the third year and is the one with the least weighting in the final grade. To be able to draw viable conclusions by academic field and year, the study should be expanded to incorporate an analysis of experiences in the three fields over the three years of the degree.

In summary, the main factors influencing the behaviour of groups involved in programmed activities for developing the competence of teamwork are the quality of the product of teamwork, the mark received for it and the weighting of teamwork in the final grade for the subject. Aside from these factors, other conclusions can be drawn from the study related to the usefulness of this method of evaluating teamwork, the tools necessary to develop it, and its interdisciplinary character. First, it has been shown that students' own evaluation of teamwork and their reflection on it constitute a useful tool for promoting students' participation and motivation in activities aimed at acquiring the competence of teamwork. This methodology is also useful for detecting divergences between team members. Moreover, if applied by all professors on a degree course, the reliability of the results could improve considerably. Second, this experience evidences that it is essential to make specific documents (individual and group reports and rubrics) available to students to help them, as well as professors, carry out the teamwork assessment. And, last but not least, the cross-disciplinary nature of this study should encourage academics from all educational fields to use self and peer assessment to evaluate teamwork.

\section{Disclosure statement}

No potential conflict of interest was reported by the authors.[AQ1]

\section{Notes on contributors[AQ2]}

\section{References}

Anson, R., and J. A. Goodman. 2014. “A Peer Assessment System to Improve Student Team Experiences.” Journal of Education for Business 89 (1): 27-34. doi:10.1080/08832323.2012.754735.

Atwater, L. E., and F. J. Yammarino. 1992. "Does Self-Other Agreement on Leadership Perceptions Moderate the Validity of Leadership and Performance Predictions?” Personnel Psychology 45 (1): 141-164. doi:10.1111/ j.1744-6570.1992.tb00848.x.

Atwater, L. E., and F. J. Yammarino. 1997. "Self-Other Rating Agreement: A Review and Model." Research in Personnel and Human Resources Management 15: 121-174.

Agència per a la Qualitat del Sistema Universitari Català- AQU. 2015. Ocupabilitat i competències dels graduats recents: L'opinió d'empreses i institucions. Principals resultats de l'etudi d'ocupadors 2014. [Employability and competences of recent graduates: The opinion of companies and institutions. Main results of the study of employers 2014]. Barcelona: Agència per a la Qualitat dels Sistema Universitari de Catalunya Catalunya.

Agència per a la Qualitat dels Sistema Universitari de Catalunya- AQU. 2017. La inserció laboral dels graduats $i$ graduades de les universitats catalanes. [Labour market insertion among Catalan university graduates]. Barcelona: AQU Catalunya.

Baker, D. F. 2008. "Peer Assessment in Small Groups: A Comparison of Methods." Journal of Management Education 32 (2): 183-209. doi:10.1177/1052562907310489.

Biggs, J., and C. Tang. 2011. Teaching for Quality Learning at University: What the Student Does. Maidenhead: McGraw-Hill Education.

Britton, E., N. Simper, A. Leger, and J. Stephenson. 2017. "Assessing Teamwork in Undergraduate Education: A Measurement Tool to Evaluate Individual Teamwork Skills." Assessment \& Evaluation in Higher Education 42 (3): 378-397. doi:10.1080/02602938.2015.1116497.

Brutus, S., and M. B. L. Donia. 2010. "Improving the Effectiveness of Students in Groups with a Centralized Peer Evaluation System." Academy of Management Learning \& Education 9 (4): 652-662. doi:10.5465/amle.9.4.zqr652.

Carson, K. M., and R. E. Glaser. 2010. "Chemistry is in the News: Assessing Intra-Group Peer Review." Assessment \& Evaluation in Higher Education 35 (4): 381-402. doi:10.1080/02602930902862826. 
Cestone, C. M., R. E. Levine, and D. R. Lane. 2008. "Peer-Assessment and Evaluation in Team-Based Learning." New Directions for Teaching and Learning 2008 (116): 69-78. doi:10.1002/tl.334.

Chapman, K. J., and S. van Auken. 2001. "Creating Positive Group Project Experiences: An Examination of the Role of the Instructor on Students' Perceptions of Group Projects.” Journal of Marketing Education 23 (2): 117-127. doi:10.1177/0273475301232005.

Channon, S. B., R. C. Davis, N. T. Goode, and S. A. May. 2017. "What Makes a 'Good Group'? Exploring the Characteristics and Performance of Undergraduate Student Groups." Advances in Health Sciences Education 22 (1): 1741. doi:10.1007/s10459-016-9680-y.

Croft, F. M., F. D. Meyers, and A. W. Fentimen. 1995. “An Algorithm for Evaluating Team Projects.” Engineering Design Graphics Journal 59 (3): 18-20.

De Hei, M. S. A., J.- W. Strijbos, E. Sjoer, and W. Admiraal. 2015. "Collaborative Learning in Higher Education: Lecturers' Practices and Beliefs.” Research Papers in Education 30 (2): 232-247. doi:10.1080/02671522.2014.908407.

European Commission. 2010. Employers' perception of graduate employability. The Gallup Organization. Flash Eurobarometer No 304.

Fundación Everis 2017. III Ranking Universidad-Empresa. Fundación Everis. Encuesta a las empresas españolas sobre la empleabilidad de los recién titulados. [III University-Company Ranking. Everis Foundation. Survey of Spanish companies on the employability of recent graduates] Accessed May 6 2019. https://www.fundacioneveris.com/ RK_Universidad_Empresa2017_fundacioneveris.pdf.

Falchikov, N., and J. Goldfinch. 2000. "Student Peer Assessment in Higher Education: A Meta-Analysis Comparing Peer and Teacher Marks.” Review of Educational Research 70 (3): 287-322. doi:10.3102/00346543070003287.

Fathi, M., M. Ghobakhloo, and A. Syberfeldt. 2019. “An Interpretive Structural Modeling of Teamwork Training in Higher Education.” Education Sciences 9 (1): 16. doi:10.3390/educsci9010016.

Fellenz, M. R. 2006. "Toward Fairness in Assessing Student Groupwork: A Protocol for Peer Evaluation of Individual Contributions.” Journal of Management Education 30 (4): 570-591. doi:10.1177/1052562906286713.

Fleenor, J. W., J. W. Smither, L. E. Atwater, P. W. Braddy, and R. E. Sturm. 2010. "Self-Other Rating Agreement in Leadership: A Review.” The Leadership Quarterly 21 (6): 1005-1034. doi:10.1016/j.leaqua.2010.10.006.

Gabelica, C., P. Van den Bossche, M. Segers, and W. Gijselaers. 2012. "Feedback, a Powerful Lever in Teams: A Review." Educational Research Review 7 (2): 123-144. doi:10.1016/j.edurev.2011.11.003.

Gómez-Ruiz, M. A., G. Rodríguez-Gómez, and M. S. Ibarra-Saiz. 2013. "Desarrollo de las competencias básicas de los estudiantes de Educación Superior mediante la e-Evaluación orientada al aprendizaje" [Development of the Basic Competencies of Students in Higher Education through e-Learning Oriented Assessment." RELIEVE - Revista Electrónica de Investigación y Evaluación Educativa 19 (1): 1-17. ]. doi:10.5944/educxx1.20184.

Gransberg, D. D. 2010. “Quantifying the Impact of Peer Evaluations on Student Team Project Grading.” International Journal of Construction Education and Research 6 (1): 3-17. doi:10.1080/15578771003590326.

Hastie, C., K. Fahy, and J. Parratt. 2014. "The Development of a Rubric for Peer Assessment of Individual Teamwork Skills in Undergraduate Midwifery Students.” Women and Birth 27 (3): 220-226. doi:10.1016/j.wombi.2014.06.003.

Ibarra-Saiz, M. S., and G. Rodríguez-Gómez. 2014. "Modalidades participatives de evaluación: Un análisis de la percepción del profesorado y de los estudiantes universitarios." Revista de Investigación Educativa 32 (2): 339-361. doi:10.6018/rie.32.2.172941.

Kiliç, D. 2016. “An Examination of Using Self-, Peer-, and Teacher-Assessment in Higher Education: A Case Study in Teacher Education.” Higher Education Studies 6 (1): 136-144. doi:10.5539/hes.v6n1p136.

King, P. E., and R. R. Behnke. 2005. "Problems Associated with Evaluating Student Performance in Groups." College Teaching 53 (2): 57-61. doi:10.3200/CTCH.53.2.57-61. 
Lejk, M., and M. Wyvill. 2001. "The Effect of the Inclusion of Selfassessment with Peer Assessment of Contributions to a Group Project: A Quantitatitve Study of Secret and Agreed Assessments." Assessment \& Evaluation in Higher Education 26 (6): 551-561. doi:10.1080/02602930120093887.[AQ3]

Loignon, A. C., D. J. Woehr, J. S. Thomas, M. L. Loughry, M. W. Ohland, and D. M. Ferguson. 2017. "Facilitating Peer Evaluation in Team Contexts: The Impact of Frame-of-Reference Rater Training." Academy of Management Learning \& Education 16 (4): 562-578. doi:10.5465/amle.2016.0163.

Loughry, M. L., M. W. Ohland, and D. D. Moore. 2007. "Development of a Theory-Based Assessment of Team Member Effectiveness." Educational and Psychological Measurement 67 (3): 505-524. doi: $10.1177 / 0013164406292085$.

Michavila, F., J. M. Martínez, M. Martín-González, F. J. García-Peñalvo, and J. Cruz-Benito. 2016. Barómetro de Empleabilidad y Empleo de los Universitarios en España, 2015 (Primer informe de resultados). [Barometer on Employability and Employment of University Students in Spain, 2015 (First Results Report)]. Madrid: Observatorio de Empleabilidad y Empleo Universitarios.

Nejad, A. M., and O. H. A. Mahfoodh. 2019. "Assessment of Oral Presentations: Effectiveness of Self-, Peer, and Teacher Assessments." International Journal of Instruction 12 (3): 615-632. doi:10.29333/iji.2019.12337a.

Neus, J. L. 2011. "Peer Assessment Accounting for Student Agreement." Assessment \& Evaluation in Higher Education 36 (3): 301-314. doi:10.1080/02602930903342315.

Ohland, M. W., M. L. Loughry, D. J. Woehr, L. G. Bullard, R. M. Felder, C. J. Finelli, R. A. Layton, H. R. Pomeranz, and D. G. Schmucker. 2012. "The Comprehensive Assessment of Team Member Effectiveness: Development of a Behaviorally Anchored Rating Scale for Self- and Peer Evaluation." Academy of Management Learning \& Education 11 (4): 609-630. doi:10.5465/amle.2010.0177.

O’Neill, T. A., G. C. Hoffart, M. J. W. McLarnon, H. J. Woodley, M. Eggermont, W. Rosehart, and R. Brennan. 2017. "Constructive Controversy and Reflexivity Training Promotes Effective Conflict Profiles and Team Functioning in Student Learning Teams.” Academy of Management Learning \& Education 16 (2): 257-276. doi:10.5465/ amle.2015.0183.

O’Neill, T., N. Larson, J. Smith, M. Donia, C. Deng, W. Rosehart, and R. Brennan. 2019. "Introducing a Scalable Peer Feedback System for Learning tea0ms." Assessment \& Evaluation in Higher Education 44 (6): 848-862. doi:10.1080/02602938.2018.1526256.

Pallisera, M., J. Fullana, E. Guiu, A. Planas, C. Serra, P. Soler, and M. Tesouro. 2009. La tutoria a la Universitat. Una proposta de Pla d'Acció Tutorial (Dos punts, 5) [Mentoring at the University. A Tutorial Action Plan Proposal (Two Points, 5)]. Girona: Universitat de Girona.

Paunonen, Sampo V., and Thomas A. O'Neill. 2010. "Self Reports, Peer-Ratings, and Construct Validity." European Journal of Personality 24 (3): 189-206. doi:10.1002/per.751.

Planas-Lladó, A., L. Feliu, F. Castro, R. M. Fraguell, G. Arbat, J. Pujol, J. J. Suñol, and P. Daunis-I-Estadella. 2018. "Using Peer Assessment to Evaluate Teamwork from a Multidisciplinary Perspective." Assessment \& Evaluation in Higher Education 43 (1): 14-30. doi:10.1080/02602938.2016.1274369.

Pujolàs, P. 2008. "Cooperar per aprendre i aprendre a cooperar: el treball en equips cooperatius com a recurs i com a contingut [Cooperate to Learn and Learn to Cooperate: Cooperative Teamwork as a Resource and as Content]." Supports 12 (1): 21-37.

Rodríguez-Gómez, G.,. M. S. Ibarra-Saiz, and J. Cubero-Ibáñez. 2018. "Competencias básicas relacionadas con la evaluación. Un estudio sobre la percepción de los estudiantes universitarios.” [Basic Skills Related to Evaluation. A Study on the Perception of University Students." Educación XX1 21 (1): 181-208. ] doi:10.5944/educXX1.20184.

Riebe, L., A. Girardi, and C. Whitsed. 2016. “A Systematic Literature Review of Teamwork Pedagogy in Higher Education.” Small Group Research 47 (6): 619-664. doi:10.1177/1046496416665221.

Scott-Ladd, B., and C. A. Chan. 2008. "Using Action Research to Teach Students to Manage Team Learning and Improve Teamwork Satisfaction." Active Learning in Higher Education 9 (3): 231-248.

doi:10.1177/1469787411429186. 
Sergi, M. 2007. "Evaluating Short-Term and Long-Term Peer Assessment of Student Teamwork." Journal of Business Education \& Scholarship of Teaching 1 (1): 41-58. E-

Sridharan, B., M. B. Muttakin, and D. G. Mihret. 2018. "Students' Perceptions of Peer Assessment Effectiveness: An Explorative Study." Accounting Education 27 (3): 259-285. doi:10.1080/09639284.2018.1476894.

Strom, P., and R. D. Strom. 2011. "Teamwork Skills Assessment for Cooperative Learning." Educational Research and Evaluation 17 (4): 233-251. doi:10.1080/13803611.2011.620345.

Thomas, G., D. Martin, and K. Pleasants. 2011. "Using Self- and Peer-Assessment to Enhance Students' FutureLearning in Higher Education." Journal of University Teaching \& Learning Practice 8 (1). [AQ4]

Villardón, L. 2006. "Evaluación Del Aprendizaje Para Promover el Desarrollo de Competencias. [Assessment of Learning to Promote Competence Development]." Educatio Siglo XXI 24: 57-76.

Vu, T. T., and G. Dall'Alba. 2007. "Students' Experience of Peer Assessment in a Professional Course." Assessment \& Evaluation in Higher Education 32 (5): 541-556. doi:10.1080/02602930601116896.

Walker, A. 2001. "British Psychology Students' Perceptions of Group-Work and Peer Assessment.” Psychology Learning \& Teaching 1 (1): 28-36. doi:10.2304/plat.2001.1.1.28.

Weaver, D., and A. Esposto. 2012. "Peer Assessment as a Method of Improving Student Engagement." Assessment \& Evaluation in Higher Education 37 (7): 805-816. doi:10.1080/02602938.2011.576309.

Wen, M. L., and C. Tsai. 2006. "University Students' Perception of and Attitudes toward (Online) Peer-Assessment." Higher Education 51 (1): 27-44. doi:10.1007/s10734-004-6375-8.

Wilson, L., S. Ho, and R. H. Brookes. 2018. "Student Perceptions of Teamwork within Assessment Tasks in Undergraduate Science Degrees." Assessment \& Evaluation in Higher Education 43 (5): 786-799.

doi:10.1080/02602938.2017.1409334.0.

\section{AUTHOR QUERIES}

Query: AQ0: Please review the table of contributors below and confirm that the first and last names are structured correctly and that the authors are listed in the correct order of contribution. This check is to ensure that your names will appear correctly online and when the article is indexed.

\begin{tabular}{|c|c|c|c|}
\hline Sequence & Prefix Given name(s) & Surname & Suffix \\
\hline 1 & Anna & Planas-Lladó & \\
\hline 2 & Feliu & Lidia & \\
\hline 3 & Gerard & Arbat & \\
\hline 4 & Joan & Pujol & \\
\hline 5 & Joan & Suñol & \\
\hline 6 & Fransesc & Castro & \\
\hline 7 & Carolina & & \\
\hline 8 & & Martí & \\
\hline
\end{tabular}

Author Response: 2- Given Name- LídiaSurname- Feliu5- Given Name: Juan Jose, Surname: Suñol7 and 8 go together: Given name: Carolina, Surname: Martí

Query: AQ1: A disclosure statement reporting no conflict of interest has been inserted. Please correct if this is inaccurate.

Author Response: Ok

Query: AQ2: Please provide the missing notes on contributors for all the authors. 
Author Response: Planas, A. Planas, A. is an Associate Professor at the Department of Pedagogy of the University of Girona. She has a background in community development and worked in the voluntary sector and youth and cultural services of local government before joining the University. She is the Social Education Degree Coordinator at the UdG since 2014. Her teaching and research focus on social pedagogy through community development, assessment, participatory evaluation, and youth and cultural policies and programs. For further details please visit his profiles on academia.edu and researchgate.net.Feliu, L. obtained a BSc degree in Pharmacy from the University of Barcelona, where she completed her PhD degree in 2000. In 2001, she obtained a two-year postdoctoral position at the University of Montpellier as Marie Curie Fellow. Following that, she moved to the University of Girona, where she obtained a Marie Curie Reintegration Grant. She joined the Department of Chemistry's LIPPSO group and became Associate Professor in 2008. Her main research topics are centered on the design and synthesis of peptides with antimicrobial and antitumor activity.Arbat, G. is an Associate Professor at the Department of Chemical and Agricultural Engineering and Food Technology at the University of Girona. His research is focused on the improvement of water and energy efficiencies in irrigation, soil water modeling under different irrigation systems and water re-use in agriculture. He is the author of several scientific papers dealing with these topics.Pujol, J. is an Associate Professor at the Department of Chemical and Agricultural Engineering and Food Technology at the University of Girona. His research has focused on issues relating to the economy of natural resources, particularly water. He is the author of several scientific papers dealing with these topics.Suñol, J. J. is Full Professor of Applied Physics at the University of Girona. His field of specialization is the production and thermal and structural characterization of new materials. He has published over 120 scientific articles and has more than 150 conference papers. He is coauthor of 8 university physics books and a member of the Royal Spanish Society of Physics' specialist physics education group.Castro, F. obtained a PhD in Computer Science (2002) from the Polytechnic University of Catalonia, where he had previously obtained a degree in Computer Science Engineering. He holds the position of Associate Professor at the University of Girona. His current research is focused, on the one hand, on the application of intelligent algorithms to different practical fields, such as medicine and interior design, and, on the other, on simulation of the illumination of interiors involving both natural and artificial light. Martí, C. is Associate Professor at the Department of Geography and Director of the Institute of the Environment at the University of Girona. She obtained a PhD on landscape (UdG, 2005) and her expertise is in Geographic Information Systems. Her research focuses on coastal landscape transformation, integrated coastal zone management and sustainable tourism strategies of mature coastal destinations. Her articles on the coastal landscape changes and integrated costal management issues have appeared in a wide variety of national and international scientific papers and general-interest publications.

Query: AQ3: The year of publication has been changed as per Crossref details both in the list and in the text for this reference. Please check.

Author Response: Ok

Query: AQ4: Please provide the page range.

Author Response: There's no page range available. You can look at the website of the Journal to see it.

Query: AQ5: Please note that the ORCID section has been created from information supplied with your manuscript submission/CATS. Please correct if this is inaccurate.

Author Response: Ok 